\title{
Water Safety Plan and Water Policy as an Instrument for Improved Quality of Drinking Water in Anambra State, Nigeria
}

\author{
Ozoh, Joan N..$^{*} \quad$ Nwogwugwu Uche C. ${ }^{2} \quad$ Uzodigwe, Anthony A. ${ }^{3} \quad$ Uzoechina, Benedict I. ${ }^{4}$ \\ 1.The Authors are of Department of Economics, Nnamdi Azikiwe University, Awka
}

\begin{abstract}
Reliable, safe drinking water and sanitation are the fundamental requirements for people trying to reach their greatest potential in life. Water and sanitation are some of the primary drivers of public health and critical elements in the Sustainable Development Goals (SDGs). A country that secures access to clean water and adequate sanitation facilities for the people irrespective of the difference in their living condition has won a huge battle against all kinds of diseases. The study empirically looks at the use of a water safety plan to know the extent to which the water is safe for drinking in Anambra State. This study is a qualitative study which the researcher adopted a descriptive approach to analyze and present data. Primary and secondary sources of data collection was used. A questionnaire was used as an instrument for data collection which involves people in the "WASH" communities while the secondary source was materials collected from health workers. The study found that the identified risks in the 2 WASH communities are: dirty fetcher, a dirty tank, dirty environment, no fence around the dug well, dirty concrete floor, cobwebs around the water tank which makes water unsafe for human consumption. The major challenges experienced by the community in providing safe water is the high cost of water treatment and inadequate finance. The study recommended that there is a need for water policy in the state and the country at large to ensure safe drinking water.
\end{abstract}

Keywords: Water policy, Water safety plan, Water quality

JEL: Q25, Q28, O18

DOI: $10.7176 / \mathrm{JESD} / 12-4-09$

Publication date: February $28^{\text {th }} 2021$

\section{Introduction}

Water is an invaluable resource for man. Reliable and safe drinking water and sanitation are fundamental requirement for people trying to reach their greatest potential in life. Water and sanitation are one of the primary drivers of public health and an important element in the Sustainable Development Goals (SDGs). A country whose access to clean water is assessed and adequate sanitation facilities provided, have won a huge battle against all kinds of water-borne diseases. (Viet-Nam \& Kunikane, 2007). As water is an essential and valuable ingredient of life, drinking safe water is extremely important both for ensuring the consumers' good health and for the proper functioning of the ecosystem (WHO \& UNICEF, 2008). Achieving universal access to safely managed drinking water and sanitation services are one of the 17 post-2015 sustainable development goals (SDGs 6) that form the core of the united nations 2030 agenda for sustainable development (Rose, 2016).

The Nigerian public sector has failed to provide the quality water and sanitation services needed in states and communities (Kuruk, 2004). Most of the water supplied is not sustainable in Nigeria because of some problems in management, operation and failure to recover costs (Federal ministry of water resources, 2000). Recently, issues on water provision have taken over by events known as sachet water and bottled water production at the expense of portable municipal water supply authorities such as water co-operation/water works established in every state of the country to provide quality drinking water. We realize that despite all these regulatory agencies like NAFDAC, SON, 30\% of Nigerians have access to safe drinking water (Enyidi, 2017).

In Nigeria, there has been a slow improvement in the supply of safe water (Ajuma, 2018). Studies have shown that population that have water safety drinking services is about $58.5 \%$ in $2011,57.8 \%$ in 2013 and $62.2 \%$ in 2014. As at 2015, It was estimated that $69.9 \%$ of Nigerian had safe sources of drinking water but there was a decline from $69.6 \%$ in 2016 to $64.1 \%$ in 2017(Ajuma, 2018). In areas with high population density, significant levels of faecal bacterial pollution migrated from septic tank clusters into the groundwater. About $70.8 \%$ of households in the country drink water contaminated by faeces and other impure substances such as Escherichia Coli (E. coli)-a bacterial pathogen which causes illness such as diarrhea, guinea worm, typhoid fever (WHO \& UNICEF, 2008). Drinking water sources are under increasing threat from contamination, with consequences for the health of children and for the social and economic development of communities and nation (Rose, 2016).

In Anambra state, there is hardly any community we can confidently assert that the inhabitants have convenient access to safe and adequate water supply (Mogbo, 2010). Today, along the roads, streets, there is solid waste which pile up, blocking the roads. When they decay, they flow into the groundwater which contaminates the water. When it rains, some of them are washed into surface water sources like streams and rivers thereby polluting them, absence of conventional waterworks, the dearth of water pumping distribution 
equipment and an unreliable electric power supply step up the problems of availability of portable water in the state. There is no water policy and this has resulted in the proliferation of wells and boreholes in which the quality and standards are not observed. No test is also done to find out the safety of the water.

By way of intervention, Government and non-governmental agencies, corporate organizations and individuals are involved in sinking boreholes to provide water for families and communities. The government has also initiated the water and sanitation projects (WATSAN), water and environmental sanitation (WES). National policy on water supply and sanitation to provide portable water and adequate sanitation to people. The world health organization has also recommended the adoption of a water safety plan approach as the most effective way of ensuring the safety of drinking water (Ezenwaji \& Phil-Eze, 2014).

Despite all these interventions, the water crisis is still a problem in Nigeria and the quality of the available water is doubtful. More than $80 \%$ of Nigerians still lack safe drinking water (Punch June,2018). The learning abilities of children who are in school are infected with intestinal worms because of unclean water. Unsafe water, poor sanitation and inadequate hygiene are a significant contributing factor to diseases such as diarrhoea which is the leading killers of children under five years of age (Smith \& Reed, 2013). UNICEF and WHO (2015) estimated that about 124,000 children under the age of 5 die because of diarrhea. WHO Guidelines for drinking quality water recommended pro-active efforts to reduce risks and prevent contamination before the water reaches the consumer. This can be achieved through a holistic risk-based approach that covers from the catchment-toconsumer. Such an approach is called Water safety plan (WSP). The implementation of WSP can contribute to reducing the portion of the global disease burden attributed to poor drinking-water and inadequate sanitation and hygiene to make sure there is safety of drinking water. UNICEF has also recommended the adoption of a water safety plan approach as the most effective way of ensuring the safety of drinking water (Ezenwaji \& Phil-Eze, 2014).

However, if water quality problem has been detected, it may not be clear what actions the community should take to correct the problem. The purpose of this study is to empirically study the use of water safety plan to know the extent to which the water is safe for drinking in Anambra State. It identified and assessed the risk on water supply, find out the measures and challenges faced by the community after detecting the risk. No study has been done in Anambra state to ascertain the safety of drinking water and this study remedies the knowledge gap. Having introduced the work in Section 1, the remaining part of the paper is structured as follows: Section 2 review literature, Section 3 assessing water policy in Nigeria. Section 4 research methodology, Section 5 analysis, presentation and discussion of data while Section 6 is on conclusion and recommendation.

\section{Review of Literature}

\subsection{Conceptual Framework}

SAFE DRINKING WATER
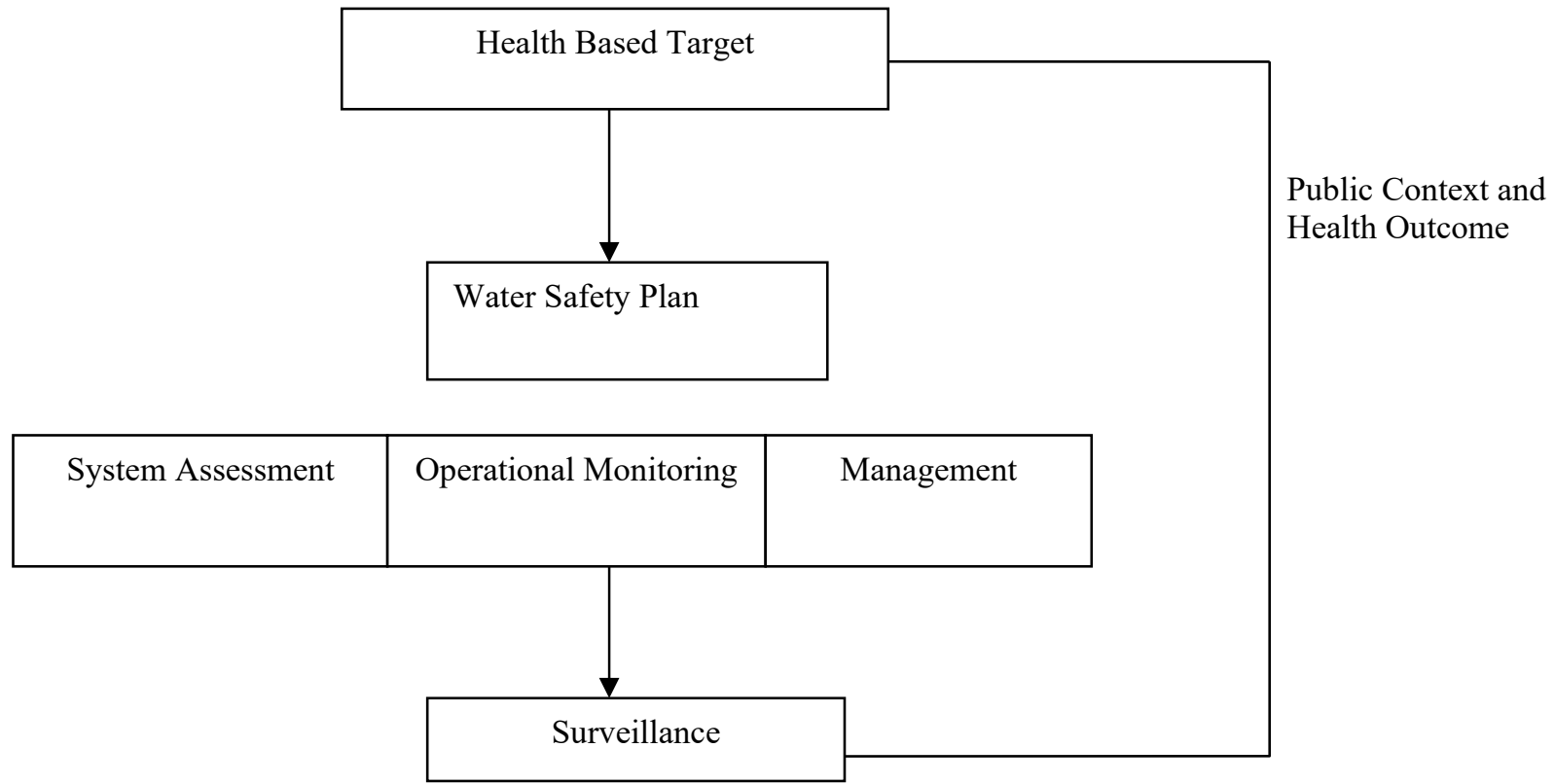

\section{Source-Unathai and Souzab (2017)}

This framework is effective in ensuring the safety of a drinking water supply which encompasses all steps in water supply from catchment to consumer. Heath-based targets are realistic under local operating conditions and are set to protect and improve public health. It supports the development of water safety plan (WSP), an 
essential component of drinking water safety, providing information with which to check the adequacy of existing installations and aid in identifying the level and type of inspection and analytical verification that are appropriate. In this, the water suppliers affected communities should take account of the public health situation and the contribution of the drinking water quality to disease due to water -borne microbes and chemicals as a part of overall water and health policy. The safety requirements are health outcome targets, Water quality targets, performance targets, and specified-technology targets. The health outcome targets have to deal with some hazards and health effects attributable to water in developing countries. It is also a basis for evaluation of results through quantitative risk assessment models. However, health outcomes are estimated based on information about exposure and dose-response relationships. The result of the health outcome will be a base for the development of other heath- based targets. Water quality targets is also established for individual drinking water constituents that represent a health risk from long term exposure. Also, performance targets are employed for constituents where short term exposure represents a public health risk or concentration can occur over a short period with significant implications on health. The specified technology targets are regulated by national agencies for specific actions for smaller community, municipal and household drinking water supplies.

System assessment is applied to large utilities with piped and non-piped community supplies including hand pumps and individual domestic supplies. Existing infrastructure can be assessed and plans made for new ones. The aim of the assessment is to determine whether the final quality of water delivered to the consumer will meet established health based targets. In the assessment, potential health hazards are identified which may affect the quality of drinking water. With the hazards established, the level of risk for each hazard can be estimated and ranked based on the severity of the consequences. After this process, validation is undertaken to ensure that the information supporting the plan is correct.

Operational monitoring is used to assess whether the community water supply is operating normally. In other words, it makes sure that control measures to prevent, reduce and remove contaminants are operating effectively. It helps to know the water quality problems so that action can be taken before the unsafe water reaches the consumers. Management deals with the documentation of all aspects of drinking water quality management. It describes the activities that are undertaken and how procedures are performed. It includes detected information in the assessment of the drinking water and the emergency response plan. Surveillance is normally carried out by public health officer or inspectors. They are responsible for an independent and periodic review of all aspects of safety. They make sure that water quality targets are being achieved and maintained and that the system is operating safely. It requires a systematic programme of surveys that may include auditing of WSP analysis, sanitary inspection. It should cover the whole of the drinking-water system which includes services and activities in the catchment, storage, reservoir and distribution system (Unathai \& Souza, 2017).

Water safety plan is a process of identifying and implementing possible and known risks in the water supply system. The process aims at ensuring acceptable drinking water quality through all stages of the water supply system (Unathai \& Souza, 2017). Bartram, Corrales, Davison, Deere, and Gordon (2009) defined water safety plan as the prevention of contamination of water from the source to the point of consumption which gives consumers greater involvement and control over maintaining water quality. Ezenwaji and phil -Eze (2014), were of the view that to ensure water safety, testing the quality of water at the point of entry to the distribution system is of great importance.

\subsection{Empirical literature}

Studies on assessment of quality of water in different areas found that most of the water are not safe for human consumption such as Shalom, Nwinyi, Adetayo and Vivienne (2011) examined water quality in Canaan land, Ota, Southwest of Nigeria. Using Some Water quality variables such as $\mathrm{pH}$, alkalinity, salinity, conductivity, turbidity, total hardness, total solids, total dissolved solids, total suspended solids, dissolved oxygen, biochemical oxygen demand, iron, lead, zinc and chromium found that water samples were slightly acidic with the exception of bottled or sachet Hebron water and Iju River water. The results were compared against drinking water quality standards laid by World Health Organization (WHO). The study found that the potable water samples were within the standards for consumable water and so are considered safe for human consumption but the Iju river water was contaminated and the use of the water for domestic purposes by the inhabitants could lead to hazardous side effects. Smiley (2017) used data from 139 household surveys from 13 villages in rural Malawi examined quality matters through incorporating water quality into access monitoring and also examined 27 drinking water sources to highlight areas where the goals' proposed monitoring framework might not fully capture water quality and found that the water quality is low. Adedayo (2018) using ANOVA, assessed the quality of water in Slum Area, Ibadan. Samples from well, borehole, vendor or pipe borne were collected from 8 localities and 3 Local government area in Ibadan and the results showed that there are variations in the water quality parameters in the slum areas. There is no significant difference between the water quality in slum areas and WHO standards and also found a significant spatial variation of water quality of Lead concentration with the sig value of 0.033 and F value of 2.983. Alfa, Ajibike and Daffi (2018) using a cross-sectional study among 325 
household heads on examined sanitation and water supply coverage in rural community of Kogi state Nigeria. The result showed that $34.77 \%$ of the household has improved sanitation while $48 \%$ defecate in the open fields and bushes. $71 \%$ do not have access to safe water.

Some studies advocated that water safety plan as a policy should be used in improving the quality of drinking water. For instance, Ezenwaji, and Phil-Eze (2014) examined water safety plan as a tool for improved quality of municipal drinking water in Nigeria. The study explained the meaning of water safety plan and highlighted its importance and the ways it can be employed to achieve enhanced piped distribution of good quality drinking water, its level of development in Nigeria, and the extent it can be employed to improve the present low health status of Nigerian urban populace in the country.

Sabrina, Biasibetti, Alessandro, Collivignarelli, and Damiani (2017) adopted risk assessment study carried out through the semi-quantitative approach and developed a proposal of Water safety plans (WSP) for the drinking water supply system (DWSS) in order to understand which are the preliminary evaluation aspects to be considered in the elaboration of a WSP. Their result found a Potential hazard in each part of the water supply system. Stoddart and Gagnon (2017) based on review of literature of Arctic jurisdictions, evaluated the current water management approaches and how those techniques could be applied to the territory of Nunavut in Canada and found that the communities in Nunavut face many challenges in delivering safe water to customers due to remoteness, small community size, lack of guidelines and monitoring procedures specific to Nunavut.

\section{Assessing water policy in Nigeria}

Some regions of the world have abundant water available while some others have a scarcity of water. Nigeria is a diverse country consisting of the arid Northern provinces and the tropical rainforest provinces of the south. Water is a factor that is very essential in human life. Most Nigerians depend on boreholes, stream, rivers which swell up during rainfall, wells and rainwater as their main source of water supply. Water is scarce and this makes it costly (Enyidi, 2017).

In Nigeria, so many regulatory authorities have been set with the government for the control and management of water resources. UNICEF in 1981, embarked on a programme known as the rural water supply and sanitation programme in states like Adamawa, Taraba, Imo, Gongola, Cross river, Anambra, kwara, and Niger. Since then, about 22 states has participated in this programme. The Federal government in decree no 15 of 1993, set up a national agency called National Agency for Food, Drugs and Administration Control (NAFDAC). This body was set up to see to the standard, inspection and regulation for the production, importation, exportation, distribution and sale of drugs, food, bottled water, sachet water etc. in the country. They also help in establishing the quality assurance of drinking water which includes issuing of a certificate to the companies that produce such products.

In 2000, the National Water Supply and Sanitation Policy (NWSSP) was introduced. This policy was aimed at stipulating guidelines for the supply of water both in urban and rural areas. In 2005, the national council on water resources (NCWR) was instituted to set up the acceptable standard for drinking quality water in Nigeria. Again, in 2007, another organization was instituted known as the Standard Organization of Nigeria (SON). The aim of this organization is to make sure that Nigeria standard for quality drinking water in Nigeria improves. Hence, they provided regulations for safe drinking water such as consumer protection act 66, Federal Environmental Protection Agency, National Water Resource Institute Act, Public Health act, Water Resource Acts no 101, International Organization for Standardization, National Guidelines and Standards for Water Quality in Nigeria and Nigerian Industrial Standards for Natural Mineral Water and Potable Water.

Today as it stands, Nigeria does not have any working national policy on water supply, the existed ones are obsolete and need to be reviewed. There is a lack of direction and regulation of state water programme resulting in almost total neglect of the states. It is therefore mandatory for the government to amend the old policies and also adopt the use of a water safety plan as a policy for the provision of safe water in the state and country at large

\section{Research Methodology}

This study used a descriptive survey research design. The population of this study is made up Households of 2 WASH communities in Anambra state. Questionnaire and secondary data were used as an instrument for data collection. The secondary data were collected from health workers. The researcher used simple random sampling to distribute the questionnaire to people found in communities in 2 WASH local governments which are Idemili south and Anambra East. The sampling frame for this study is the WASH communities in Anambra state. The sampling unit are the individuals. The population of households in the 2 WASH communities are 358,968(2006 population census). The sample size is determined using Kothari's formula

$$
n=(\mathrm{z})^{2} p q N
$$

$$
c^{2}(N-1)+z^{2} p q
$$

where $\mathrm{n}=$ Required sample size 


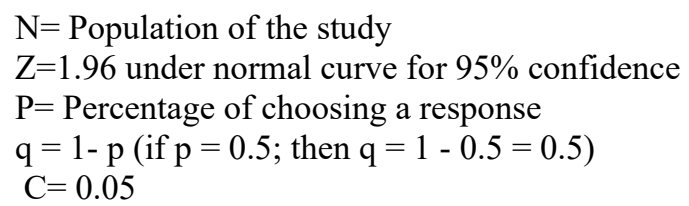

From the formula, the sample size $\mathrm{n}=\frac{1.96^{2 *}(0.5) *(0.5) * 358,968}{(0.96) *(358,68-1)+(1.962) *(0.5}$

$$
\begin{aligned}
& \left.(0.05)^{2 *}(358,968-1)+\left(1.96^{2}\right) *(0.5) *(0.5)\right) \\
= & 383.75
\end{aligned}
$$

The sample size for this study is 400 .

\section{Result Presentation and Discussion}

\section{Results of UNICEF Supported Project in WASH Areas}

We begin by presenting the results of UNICEF supported project activities by health workers in Idemili South and Anambra East Local Government Areas in 2018. Some selected communities in the two of the WASH Local Government Areas in Anambra State were visited by the health workers to identify the risk and test the water sources. The results of the water tested at sources, transport and storage are as follows: + means positive (risk) while -means negative (No risk)

Table 4.1-Result of Unicef supported Project in Idemili LGA

\begin{tabular}{llll}
\hline Community boreholes & Source & Transort & Storage \\
\hline UbiliNnokwa (Private) & - & + & + \\
UmuaforNnobi (Ruwassa) & - & + & + \\
UmuokaNnobi & - & + & + \\
Umunocha Awka-Etiti(Ruwassa) & + & + & + \\
Ogunzelle Awka-Etiti(Ruwassa) & - & + & + \\
UmuokpalaNnobi & - & + & + \\
Uruagu Oba(Private) & - & + & + \\
Umuezeokpala Oba (Private) & + & + & + \\
Ogwugwu Oba(Private) & + & + & + \\
Umuabu Oba(Private) & - & + & + \\
EkeleAkwa-Ukwu(Private) & - & + & + \\
NgogwugwuOjoto(Govt) & + & + & + \\
UmuezemaOjoto(Private) & - & + & + \\
UmuoshiAlor(Private) & - & + & + \\
IsiekeAlor(Private) & - & - & -
\end{tabular}

\section{Source: UNICEF Supported Project Activities by Health Workers in Idemili South local Government,} 2018

From table 4.1, 15 communities were tested at source, transport and storage. It was found that out of the 15 communities whose borehole and water harvesting tank were tested. It was found that 11 communities were negative at source while 4 communities were positive. This means that where the water is collected from is not risky for human consumption.

The water was also tested at transport in the 15 communities that uses Jerri cans, bucket to collect water for their domestic purposes. It was also found that 14 communities were positive while 1 community is negative. This means that what is used to transport water for drinking and domestic purposes is very risky for human health.

At the storage, it was also found that 14 communities were found to be positive while 1 community is found negative. This indicates that what is used to store water (i.e. the tanks, reservoir, well etc.) in these areas are at a very high risk. Therefore, in Idemili, Water is not risky at source but are very risky at transport and storage. This means that the water in Idemili South is not safe for human consumption 
Table 4.2: Results of UNICEF Supported Project in Anambra East LGA

\begin{tabular}{llll}
\hline Community borehole & Source & Transport & Storage \\
\hline Umuoba Anam(Private) & + & - & + \\
Nando (Govt) & + & + & + \\
EnugwuAguleri(Private) & + & - & + \\
IkemIvite (Private) & + & - & + \\
Igbariam (Private) & + & - & + \\
Enugwu Out (Private) & + & - & + \\
IgborazunuAguleri (Private) & + & - & + \\
Nsugbe(Ruwassa) & - & - & + \\
Eziaguluotu (Private) & + & - & + \\
UmuatuwoluUmeri (Private) & + & + \\
IgboezunuAguleri (Private) & - & + \\
MkpunandoOtu(Ruwassa) & + & + & + \\
\hline Source: UNICEF Supported Project Activities $b y$ Health & & \\
\hline
\end{tabular}

Source: UNICEF Supported Project Activities by Health Workers in Anambra East Local Government, 2018.

From Table 4.2, 12 communities water were tested at source, transport and storage. It was found at the source, 10 communities tested positive while 2 tested negative. This means that where the water is gotten (i.e. the Boreholes) is at high risk in Anambra East local government. At the transport, it was found that 10 communities were negative while 2 was positive. This indicates that what is used to transport water is not at risk at this local government. At storage, it was found that 12 communities were positive. This indicates that what is used to store water (i.e. the tank, well, reservoir) are at a very high risk. This indicates that the water is not good for human consumption. Therefore, in Anambra East Local government, Water is risky at source and storage. We conclude that water is not also safe for drinking in the area.

\section{Preliminary Analysis: Descriptive Statistics}

Two hundred (200) questionnaires each were administered to randomly selected participants in Anambra East and Idemili South Local Government Area. Out of 200 questionnaires administered to respondents in Anambra East LGA, 178 of them (which represents 89\% response) rate were returned. On the other hand, 188 of 200 questionnaires administered to respondents in Idemili South were returned. This also represents $94 \%$ response rate. As a preliminary, we present the descriptive statistics of the participants in these two WASH areas. The results are summarized in Table 4.3.

Table 4.3: Characteristics of the participants in the WASH communities

\begin{tabular}{|c|c|c|c|c|c|}
\hline \multirow[t]{2}{*}{ Variable } & \multirow[t]{2}{*}{ Category } & \multicolumn{2}{|c|}{ Anambra East } & \multicolumn{2}{|c|}{ Idemili South } \\
\hline & & Frequency & Percentage & Frequency & Percentage \\
\hline \multirow[t]{4}{*}{ Age } & 15 years -35 years & 47 & $26.4 \%$ & 45 & $23.9 \%$ \\
\hline & 36 years -56 years & 74 & $41.6 \%$ & 87 & $46.3 \%$ \\
\hline & 56 years and above & 57 & $32 \%$ & 56 & $29.8 \%$ \\
\hline & Total & 178 & $100 \%$ & 188 & $100 \%$ \\
\hline \multirow[t]{3}{*}{ Gender } & Male & 102 & $57.3 \%$ & 112 & $59.6 \%$ \\
\hline & Female & 76 & $42.7 \%$ & 76 & $40.4 \%$ \\
\hline & Total & 178 & $100 \%$ & 188 & $100 \%$ \\
\hline \multirow[t]{4}{*}{ Marital Status } & Married & 98 & $55.1 \%$ & 110 & $58.5 \%$ \\
\hline & Widowed & 44 & $24.7 \%$ & 45 & $23.9 \%$ \\
\hline & Single & 36 & $20.2 \%$ & 33 & $17.6 \%$ \\
\hline & Total & 178 & $100 \%$ & 188 & $100 \%$ \\
\hline Educational & Primary & 43 & $24.2 \%$ & 34 & $18.1 \%$ \\
\hline \multirow[t]{3}{*}{ Qualification } & Secondary & 92 & $51.7 \%$ & 94 & $50 \%$ \\
\hline & Tertiary & 43 & $24.2 \%$ & 60 & $31.9 \%$ \\
\hline & Total & 178 & $100 \%$ & 188 & $100 \%$ \\
\hline
\end{tabular}

Source: The authors, based on field survey, 2019

Table 4.3 shows the characteristics of the participants in the WASH communities in Anambra East and Idemili South Local Government Areas. We show the age distribution, sex distribution, the marital status as well as the educational qualification of the respondents. Generally, our sample is a good representation of the population, it cut across every facet of the communities. For instance, age-wise, almost everybody represented. The same applies to gender, marital status and educational qualification. 
Table 4.4: The Responses of the Residents to some Questions

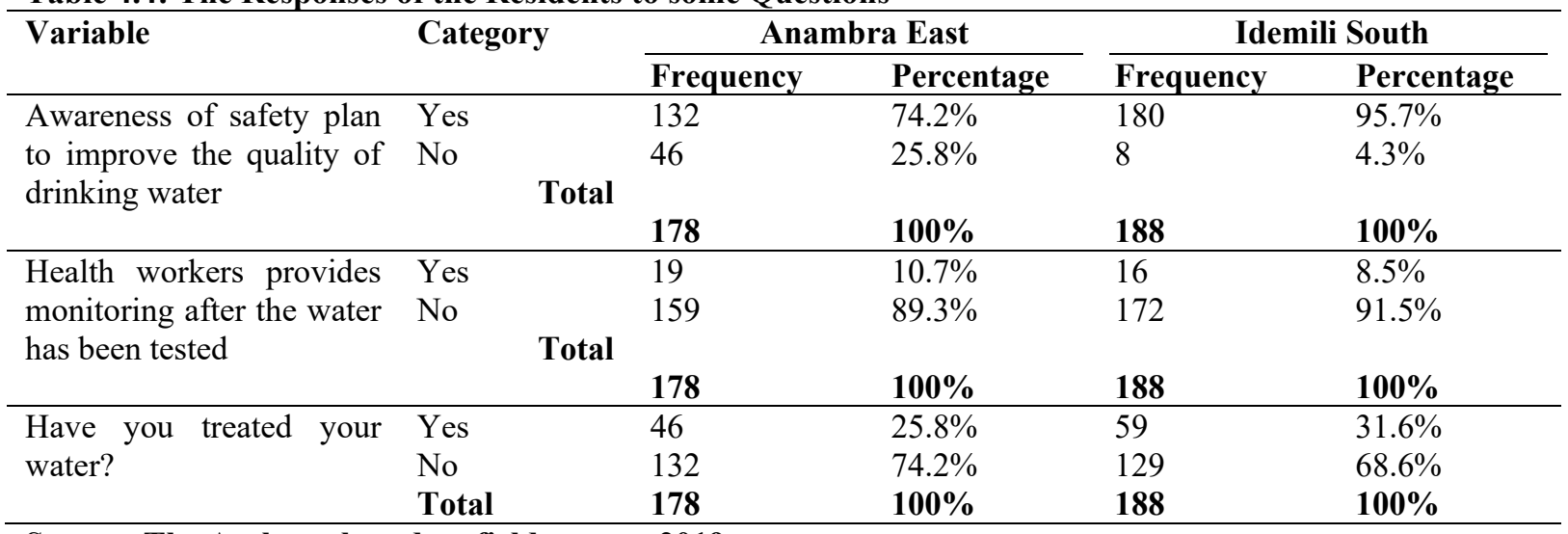

Source: The Authors, based on field survey, 2019

In Table 4.4, we show the responses of the particpants to some questions. The results show that 132 and 180 respondents are aware of the safety plan by the health workers to improve the quality of drinking water in communities in Anambra East and Idemili LGAs respectively. However, 54 residents in both local government areas are not aware of any such plan. On whether health workers provide monitoring after the water has been tested, it is generally agreed in both WASH areas that health workers do not provide monitoring after the water has been tested. Further, there is general consensus that water treatment is rare in the WASH areas.

Table 4.5: Risk Associated with Water supply in WASH Communities

\begin{tabular}{|c|c|c|c|c|c|c|}
\hline Dirty tank & 14 & $7.9 \%$ & 48 & $25.5 \%$ & 62 & $17 \%$ \\
\hline Concrete floor dirty & 16 & $9 \%$ & 4 & $2.1 \%$ & 20 & $5 \%$ \\
\hline Damaged tap & 8 & $4.5 \%$ & & & 8 & $2 \%$ \\
\hline Blocked or dirty gutter & 8 & $4.5 \%$ & 4 & $2.1 \%$ & 12 & $3 \%$ \\
\hline Using nylon to cover Jerri cans & 9 & $5.1 \%$ & 7 & $3.7 \%$ & 16 & $4 \%$ \\
\hline Dirty fetcher & 51 & $28.7 \%$ & 37 & $19.7 \%$ & 88 & $24 \%$ \\
\hline Dirty environment where water is stored & 13 & $7.3 \%$ & 21 & $11.2 \%$ & 34 & $9 \%$ \\
\hline Cobwebs around the water tank & 12 & $6.7 \%$ & 36 & 19.1 & 48 & $13 \%$ \\
\hline No fence around the perimeter of the borehole & 35 & $19.7 \%$ & 16 & $8.5 \%$ & 51 & $14 \%$ \\
\hline Septic tank near the borehole. & 12 & $6.7 \%$ & 15 & $8 \%$ & 27 & $7 \%$ \\
\hline Total & 178 & $100 \%$ & 188 & $100 \%$ & 366 & $100 \%$ \\
\hline
\end{tabular}

Source: The authors, based on field survey, 2019

Table 4.5 shows the various risks associated with water supply in the WASH communities as identified by the respondents. We show the frequency as well as the percentage of the respondents identifying one risk or the other. In Anambra East LGA, the top five risks identified include: dirty fetcher; no fence around the dug well, dirty concrete floor; dirty tank and dirty environment. Similarly, the top five risks identified in Idemili South include: dirty tank; dirty fetcher; cobwebs around the water tank; dirty environment and unfenced well. Generally, the top five risks are: dirty fetcher; dirty tank; unfenced well; cobwebs around the tank and dirty environment where water is stored.

Table 4.6: Measures taken to correct the identified risks

\begin{tabular}{|c|c|c|c|c|c|c|}
\hline \multirow[t]{2}{*}{ Measures to correct Risk } & \multicolumn{2}{|c|}{ Anambra East } & \multicolumn{2}{|c|}{ Idemili South } & \multicolumn{2}{|c|}{ Total } \\
\hline & Freq. & $\%$ & Freq. & $\%$ & Freq. & $\%$ \\
\hline Stopped the use of nylon bags & 17 & $9.6 \%$ & 36 & $19.1 \%$ & 53 & $14.5 \%$ \\
\hline Keeping the fetcher clean & 47 & $26.4 \%$ & 57 & $30.3 \%$ & 104 & $28.4 \%$ \\
\hline Covering the water receptacle & 7 & $3.9 \%$ & 22 & $11.7 \%$ & 29 & $7.9 \%$ \\
\hline Clean environment & 46 & $25.8 \%$ & 11 & $5.9 \%$ & 57 & $15.6 \%$ \\
\hline Removal of cobwebs regularly & 33 & $18.5 \%$ & 43 & $22.9 \%$ & 76 & $20.8 \%$ \\
\hline Fence the perimeter of borehole & 28 & 15.7 & 19 & $10.1 \%$ & 47 & $12.8 \%$ \\
\hline Total & 178 & $100 \%$ & 188 & $100 \%$ & 366 & $100 \%$ \\
\hline
\end{tabular}

Source: The authors, based on field survey, 2019

Table 4.6 shows the various measures taken by the residents of the WASH communities to correct identified risks associated with water supply. In Anambra East LGA, the top three measures taken to correct these risks include: keeping the fetcher clean; making the environment clean and regular removal of cobwebs. Similarly, the top three measures taken to correct these risks in Idemili South include: keeping the fetcher clean; regular removal of cobwebs and avoiding the use of nylon bags. However, the top three measures taken by the residents of all the WASH communities in the study areas to correct the identified risks include: keeping the 
fetcher clean; regular removal of cobwebs and making the environment clean.

Figure 4.1: The challenges faced by the residents in the community in providing safe water

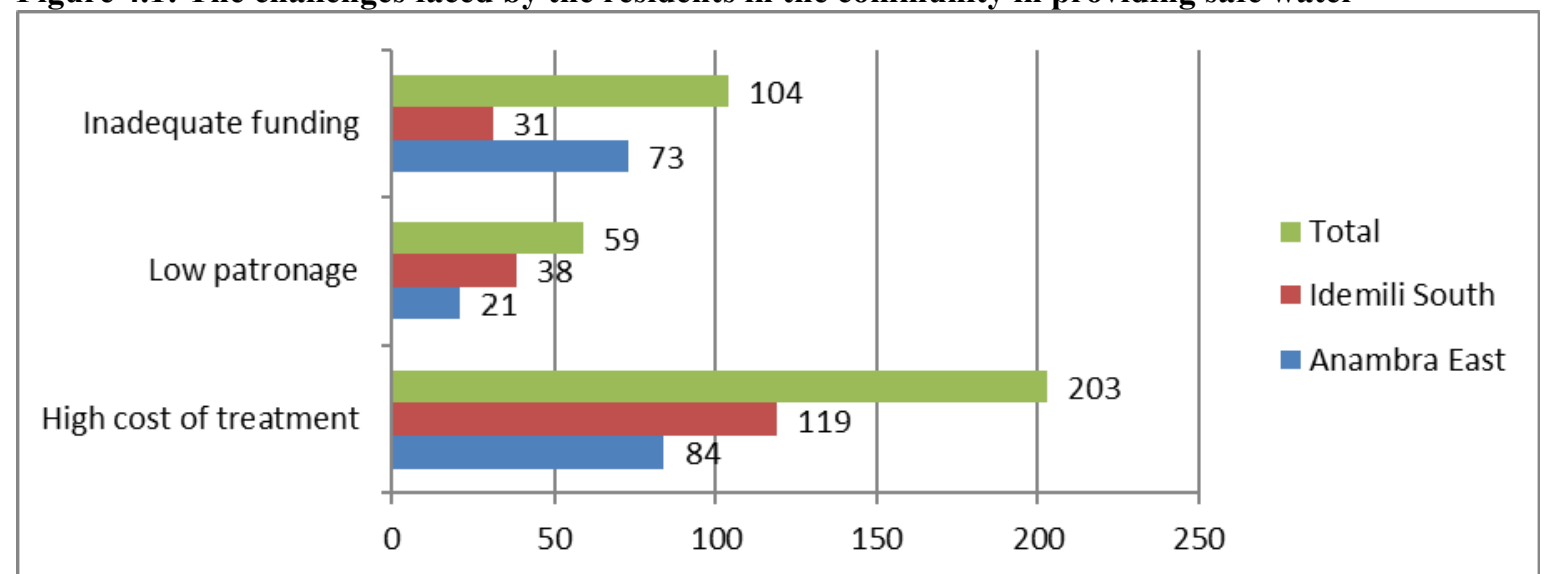

Source: The authors, based on field survey, 2019

Figure 4.1 shows the breakdown of the challenges the communities in the WASH areas face in providing safe water. In Anambra East and Idemili South LGAs, the residents identified high cost of water treatment, inadequate finance and low patronage by customers as their challenges in providing safe water. This study found that the greatest challenges faced by these communities are high cost of treatment and lack of finance.

\section{Conclusion and Recommendation}

Water is an essential and valuable ingredient of life. Drinking safety water is extremely important both for the consumers' good health and proper functioning of the body system. Achieving universal access to safely managed drinking water and sanitation services is one of the 17 post-2015 sustainable development goals (SDGs 6) that form the core of the United Nations 2030 agenda for sustainable development. From the analysis, we found that most of the risk identified in those communities were dirty fetcher, dirty tank/reservoir, dirty environment, no fence around the dug well, dirty concrete floor and cobwebs around the water tank. We also found that the most challenges faced by the communities in providing safe water are high cost of water treatment and inadequate finance. The study also found that drinking water in Anambra state is at a very high risk and not good for human consumption. Water quality deteriorates during storage. Water being clean and safe at the source can as well not be clean at the point of use. This is due to transportation or storage. Water can be contaminated as it is removed from the source using dirty fetcher, dirty containers which are not washed often. This effect is obvious and worrisome. Thus we make the following recommendations

First, government should as much as possible implement the water policy system in the country. The government in collaboration with the communities should make effort to implement water safety plan as part of the water policies for improving the water safety and quality. This will also go a long way in helping to prevent hazards, unknown risk, assessment and management of risk. There should also be Certificate of Risk policy in which every individual or community should show or the water source sealed. Second, the government should also set up committees that will from time to time visit the communities, sensitize them on the risk of unsafe water and make sure they comply with the policies set up by the government in order to minimize the contamination of water from source, transport and storage. Third, the government should also provide free treatment of water in all communities in Anambra state. This will go a long way in reducing the health risk of unsafe water supply in the area.

\section{References}

Adedayo, A. (2018). Assessment of water quality in slum area Ibadan. Hydrology Current Research. 9(1), 1-20

Ajuma, E. O. (2018). Nigerian's water need and dangers of contaminated water. Retrieved from https//www.blueprint.ng/nigers.

Alfa, M. I., Ajibike M.A., \& Daffi, R., F. (2018). Assessment of sanitation and water supply coverage in a rural community of Kogi state, Nigeria. Asian Journal of Environment and Ecology,6(4),1-8.

Bartram, J., Corrales, L., Davison, A., Deere, D., Drury, D., Gordon, B., Howard, G., Rinehold, A. \& Stevens M. (2009). Water safety plan manual: step-by-step risk management for drinking-water suppliers. Geneva, World Health Organization.

Dionysiso S. T., \& Tsitsifli, S. (2018). A critical evaluation of water safety plans (WSP) and haccp implementation in water utilities. Proceedings, 2(600), 1-8.

Enyidi, U. D. (2017). Potable water and national policy in Nigeria. Journal of Agricultural Economics and Rural Development,3(2),105-111. 
Ezenwaji, E.E., \& Phil-Eze O. P. (2014). Water safety plan as a tool for improved quality of municipal drinking water in Nigeria. Journal of Environmental Protection.5(11), 997- 1002.

Federal Ministry of Water Resources report (2000). National water supply and sanitation policy. FederalRepublicofNigeria,http://www.nwri.gov.ng/userfiles/file/National_Water_Supply and Sanitation Policy.pd

Federal ministry of water resources report (2016). Draft national water policy. official documents. Abuja, Nigeria.

Kaycie, L., Stoddart A, K., \& Gagnon, G.A. (2017). Water safety plans as a tool for drinking water regulatory framework in Arctic communities. Environ Sci Pollute. Doi;10.1007/g11356-017-96/8-9.

Kuruk, P. (2004). Customary water laws and practices: Nigeria. http://www.fao.org/legal/advserv/FAOIUCNcs/Nigeria.p d

Mogbo, C. K. (2010). Facing the water and sanitation challenges in Anambra state. A paper presented on Environmental health week held at Awka, Anambra state.

Punch Newspaper (2018, June 25). More than $80 \%$ of Nigerians lack safe drinking water. Retrieved from http://www.punchng.com

Rose, J. B. (2016). Meeting the goals of safe drinking water and sanitation. Retrieved from https://waterandhealth.org/safe-drinking water

Sabrina, S., Biasibetti, M., Alessandio, A., Collivignarelli M.C., Damuni S. (2012). Water safety plan for drinking water risk management: The case study of Mortara Italy. Ambiente\& Ajua-An Interdisciplinary Journal of Applied Science. Doi;10.4136/ambi-agua.2102.

Shalom N.C, Nwinyi, O. C., Adetayo Y O., \& Eze,V. N.,(2011). Assessment of water quality in Canaanland, Ota, South west, Nigeria. Agriculture and Biology Journal of North America. 2(4),577-583

Smiley, S. L. (2017). Quality matter incorporating water quality into water access monitoring in rural Malawi. Water International. Doi10. /080/o2508060.2017.1344818

Smith, M., \& Reed, B. (2013). An introduction to water safety plan. Fact sheet 8 WEDC publication

UNESCO (2008). Water for people, water for life; The United Nations world water development report; United Nations Educational, Scientific and Cultural Organization: Paris, France

UNICEF \& WHO (2015). Progress on sanitation and drinking water: 2015 update and MDG assessment. Geneva: WHO

WHO \& UNICEF (2008). Progress on drinking water and sanitation: Special focus on sanitation. World Health Organization and United Nations Children's Fund Joint Monitoring Programme for Water Supply Sanitation (JMP): Geneva, Switzerland.

Viet Nam, H., \& Kunikane S. (2007). Water safety plan: An effective tool for drinking water quality management. Retrieved from www.water safety.pdf.

Unathai, J., \& Souza, P. (2012), Guidelines for using the web enabled water safety plan. Report to water research committees, Gezina, South Africa. 